\title{
11 de Agosto de 1932 - Oração que comoveu as Arcardas e São Paulo.
}

\author{
Alcântara Machado \\ Professor de Direito e de Civismo
}

\begin{abstract}
Discurso proferido pelo presidente do C.A. XI de Agosto, Lauro Celidônio Gomes dos Reis Filho.
\end{abstract}

Alcântara Machado, o inesquecível e saudoso mestre de Direito e de Civismo, na lendária comemoração do dia 11 de Agosto, em 1932, nas Arcadas, na qualidade de diretor, pronunciou esta comovente oração, que ficou eternamente gravada na memória de todos os paulistas de 32 e ela forma uma das mais belas páginas da nossa literatura:

"O milagre do rádio permite ao homem compartir com Deus o poder de omnipresença. Apertamos, através do espaço, contra o peito os corações fraternos e entre os dedos as mãos amigas. Fechai os olhos, para que a ilusão seja completa, meus queridos e incomparáveis estudantes da Faculdade de Direito de São Paulo."

Venho convidar-vos a assistir comigo à sessão comemorativa da data luminosa de 11 de Agosto.

A Congregação acaba de entrar no salão nobre da Escola, tão vosso conhecido.

Está completa: compareceram todos - vivos e mortos. Ramalho, Crispiniano, José Bonifácio, o Moço, João Monteiro, Brasílio Machado, Pedro Lessa, João Mendes saem da tela, do mármore, do bronze e tomam assento no doutoral. Porque todos compreendem que a sessão de hoje é a mais solene de quantas se realizaram nesta Casa; e que nunca se fez mais oportuna a afirmação de que a Faculdade é o sacrário da lei, o sensório jurídico do país. A parte reservada ao auditório, aquela que costumais enfeitar com a vossa mocidade e alegrar com a vossa turbulência, parece vazia. Mas, se prestardes atenção, vereis que se vai povoando de sombras. São os manes de quantos vos procederam nas arcadas do velho mosteiro franciscano, sabendo-vos empenhados em defender as fronteiras territoriais de São Paulo, hoje confundidas com as fronteiras morais da nacionalidade, vêm ocupar 
os lugares reservados aos estudantes. Dos corpos vaporosos só distinguimos as cabeças iluminadas pela imortalidade. Aparecem-nos todos, restituídos à juventude, tais quais forjaram o espírito, laminaram a palavra, fortificaram a consciência nesta fábrica de homens livres, nesta oficina de cidadãos.

Na multidão que se acotovela não custa divisar as maiores figuras da nobiliarquia espiritual do Brasil. Ali estão reunidos Rui Barbosa, Joaquim Nabuco, Silveira Martins. Os poetas constituem um grupo numeroso, dominado pelos três nomes tutelares da Faculdade. Veremós claramente a cabeleira romântica, a fronte escampada, os olhos ardentes de Castro Alves, os olhos pensativos de Âlvares de Azevedo, os olhos amortecidos pela insônia de Fagundes Varela. Outros se lhes juntam: Bernardo Guimarães, Pedro Luiz, Raimundo, Copelos, Ricardo Gonçalves. Em torno de Teixeira de Freitas e Lafayete. Mas para quê continuar? Nenhuma geração se esqueceu de mandar os seus delegados mais representativos.

Dos professores vivos não há quem se atreva a falar. Mas de repente assoma à tribuna o último Andrada; e, no silêncio que se faz mais largo, e mais profundo, aquele verbo, que matou a escravidão, dirige a cada um de vós, revolucionários de 9 de julho, o mesmo elogio, com que saudou a Gabriel dos Santos, revolucionário de 42:

$$
\begin{aligned}
& \text { "Soldado da liberdade } \\
& \text { não renegaste a bandeira } \\
& \text { nas horas de tempestade. " }
\end{aligned}
$$

Brasílio Machado se levanta: e transpassando-vos a alma com o olhar flamejante, repete a peroração de um de seus discursos:

"Para nós, se é mister que a espada fulgure, tomemô-la, não para suspender o espólio dos vencidos, mas as duas conchas serenas da Justiça !"

João Mendes quer dizer-vos alguma cousa. Não pode. Com um soluço na garganta, levanta simplesmente a mão trêmula e traça no ar uma benção...

Agora são os moços de todos os tempos que têm a palavra Fagundes Varela:

"Basta de humilhações!.
A terra de Cabral está cansada
de ultrajes suportar. A seus clamores
no seio das florestas ressuscita
um mundo de guerreiros que não teme
o troar dos canhões. Um povo ardente
se levanta inspirado.
do pendão auriverde à sombra amiga"

Vem a seguir Castro Alves:

“. . Eu sei que a mocidade 
Das mãos do Eterno recebe as tábuas da lei. Marchai! Quem cai na luta com glória tomba nos braços da história, no coração do Brasil".

$\mathrm{E}$, depois, voltando-se para outros, que não os paulistas e os que se batem ao vosso lado, ei-lo que prossegue:

"Basta de cobardia! A hora sôa

e vós cruzais os braços. . Cobardia!

E murmurais com fera hipocrisia:

Mas esperar o quê?"

Pedro Luiz não se contém; e conclama evocando a figura de Nunes Machado:

"Vem dizer aos guerreiros do futuro que, se caso o horizonte está escuro, nem por isso eles devem vacilar.

Vem dar força dos bravos à fineira, que eles hão de seguir tua bandeira

e com ela na frente hão de marchar".

Quem é aquele mestiço, que vem de Recife trazer-vos o seu estímulo? Tobias Barreto. Lá não quiseram ouvi-lo. Não faz mal. Escutai estes versos, que, feitos para outros, são vossos, exclusivamente vossos:

"Juntemos as almas gratas

de colegas e de irmãos.

$O$ vento que acorda as matas

nos tira os livros das mãos.

A vida é uma leitura.

$\mathrm{E}$ quando a espada fulgura,

quando se sente bater

no peito heróica pancada

deixa-se a folha dobrada

enquanto se vai morrer".

Um moço franzino, pequenino, mofino se aproxima da tribuna; e de súbito se transforma num gigante. É Rui Barbosa, é o verbo do direito, é o condestável da liberdade, é a voz augusta do semeador das palavras eternas: "Debaixo destes textos duas evidências há que nos consolam, nos desmaginam e chegam a desconvencer-nos da morte: a continuidade da tradição e a continuidade da justiça. Bolonha, famosa outrora entre as cidades letradas (. . ) se chamava por antonomásia, a um tempo, a douta e a livre, associando nas suas antigas moedas à legenda solene de seus direitos, libertas, o foro por exelência de mestra: Bononia docet. A São Paulo, indisputavelmente, lhe cabem os dois títulos no mesmo brasão: professa a liberdade e ensina a justiça". 
Depois de Rui ninguém tem mais o que dizer. $\mathrm{E}$ a assembléia se dissolve, enquanto Bittencourt Sampaio entoa, acompanhado por Carlos Gomes, uma das estrofes do hino acadêmico, estrofe que vai de quebrada em quebrada afirmar a nossa terra, ainda e sempre, que hoje como mais do que ontem e menos do que amanhã.

"O Brasil quer a luz da verdade

e uma coroa de louros também.

Só as leis que nos dêem liberdade

ao gigante das selvas convêem".

Eis aí o que foi neste ano glorioso de 1932 a sessão comemorativa da fundação dos cursos jurídicos, meus queridos discípulos. Discípulos? Não. Porque a vossa atitude em 23 de Maio e em 9 de julho inverteu os valores e destituiu de seus cargos todos os mestres. Os únicos professores que hoje existem no território nacional, sois vós e os vossos companheiros de armas. A trincheira é a vossa cátedra. E o Brasil inteiro está aprendendo convosco: o Brasil sitiado pelas trevas, amordaçado pela censura, emasculado pelo horror das responsabilidades, e o Brasil que para a vossa vitória trabalha nas oficinas e nos campos, nos hospitais e nos transportes; o Brasil que em vão procura limpar na bacia de Pilatos as manchas do sangue do Justo, e o Brasil que vos ajuda a carregar a cruz do sacrifício. Com o coração dilatado de orgulho e os olhos rasos de lágrimas, em nome da Faculdade de Direito, eu vos saúdo, nesta hora em que fazeis à pátria a oblação sublime de vossa vida, meus jovens professores de bravura consciente, de dignidade cívica e de heroísmo.

\section{A Lição aos Moços}

\section{Pedro de Oliveira Ribeiro Neto}

Olho as velhas mesas de possiveis glórias que ninguém contesta, a recontar histórias daqueles que viveram numa velha escola que guardam seus nomes para toda a vida, como se estivessem caminhando ainda pelos corredores ou pelas arcadas, inspirando sonhos à geração que passa.

E a gente pensa que existem presidentes

e mestres de Direito e de Oratória, e poetas célebres entre os velhos nomes que são só lembranças.

Uns fizeram tanto, outros se apagaram só Deus sabe como, mas todos gravaram seus passos na vida e sonharam juntos 
ter a glória um dia de ficar na escola, junto aos outros moços para todo o sempre.

Este o exemplo vivo que nos ensinaste e ainda nos ensinas, minha Faculdade, - é que a vida passa e a mocidade fica, desconhecida embora, renovada sempre, anônima e feliz, eterna mocidade cada vez mais viva, cada vez mais rica. 